\title{
Pelaksanaan Program Keping Emas Pada Ibu Hamil Kekurangan Energi Kalori dan Anemia Di Desa Kronjo Tahun 2019
}

\author{
M. Ikhsan Akbar, Yani Sandra Rinaningsih, Retno Ekawaty, Ni Made Padma Batiari, \\ Irfan Abdussalam, Exkuwin Suharyanto, Deasy Widiana, Yeny Sulistyowati \\ Universitas Respati Indonesia \\ Email: yeny.sulistyowati@urindo.ac.id
}

\begin{abstract}
ABSTRAK
Anemia dan Kekurangan Energi Kronik (KEK) pada Ibu Hamil adalah kasus penting pada kehamilan. Data World Health Organization (WHO) secara global, prevalensi anemia pada ibu hamil diseluruh dunia adalah sebesar $41.8 \%$. Kebanyakan anemia dalam kehamilan di sebabkan oleh defisiensi besi, pendarahan akut dan ketidakseimbangan asupan gizi. Penelitian juga menunjukkan bahwa proses tumbuh kembang janin dipengaruhi oleh kondisi fisik dan kesehatan ibu waktu remaja dan akan menjadi ibu. Dengan demikian upaya untuk mencegah gangguan tumbuh kembang janin sampai menjadi kanak kanak usia 2 tahun difokuskan pada ibu hamil. Penelitian ini bertujuan untuk menganalisis secara deskriptif faktor risiko Ibu hamil pada pelaksanaan program Keping Emas di Desa Kronjo Tahun 2019. Pada penelitian menggunakan data sekunder dari pengukuran haemoglobin $(\mathrm{Hb})$ dan lingkar lengan atas (LILA) Ibu hamil risiko tinggi di Desa Kronjo dalam Program Keping Emas tahun 2019. Total sampel pada penelitian ini sebanyak 18 reponden ibu hamil risiko tinggi. Teknik pengambilan sampling yang digunakan adalah total sampling. Hasil penelitian menunjukkan ecara keseluruhan gambaran karakteristik umur ibu hamil berisiko tinggi yang terlibat dalam pelaksanaan Program Keping Emas di Desa Kronjo Tahun 2019 terdapat pada kelompok umur dewasa (26-35 tahun). Terdapat sebanyak 8 orang $(44,4 \%)$ ibu hamil risiko tinggi anemia dan 5 orang $(27,8 \%)$ ibu hamil berisiko tinggi KEK pada pelaksanaan bulan pertama (September 2019), serta terdapat terdapat 5 orang $(27,8 \%)$ yang mempunyai status anemia dan KEK berdasarkan indikator kadar $\mathrm{Hb}$ dan LILA.
\end{abstract}

Kata kunci : Anemia ibu hamil, KEK, TTD, keping emas

\section{ABSTRACT}

Anemia and Chronic Energy Deficiency (KEK) in Pregnant Women are important cases in pregnancy. Data from the World Health Organization (WHO) globally, the prevalence of anemia in pregnant women around the world is $41.8 \%$. Most anemia in pregnancy is caused by iron deficiency, acute bleeding and an imbalance in nutrition. Research also shows that the process of fetal growth and development is influenced by the physical condition and health of the mother as a teenager and will become a mother. Thus efforts to prevent fetal growth and development disorders to become children aged 2 years focused on pregnant women. This study aims to descriptively analyze risk factors for pregnant women in implementing the Gold Chip program in Kronjo Village in 2019. In this study, secondary data from hemoglobin $(\mathrm{Hb})$ measurements and upper arm circumference (LILA) for high risk pregnant women in Kronjo Village in Keping Program Gold in 2019. Total samples in this study were 18 respondents with high risk pregnant women. The sampling technique used is total sampling. The results showed that the overall description of the age characteristics of high risk pregnant women involved in the implementation of the Gold Chip Program in the Village of Kronjo in 2019 was found in the

http://ejournal.urindo.ac.id/index.php/kesehatan

Article History : 
adult age group (26-35 years). There were 8 people (44.4\%) pregnant women with high risk of anemia and 5 people (27.8\%) pregnant women with high SEZ risk during the first month (September 2019), and there were 5 people (27.8\%) who have anemia and KEK status based on $\mathrm{Hb}$ and MUAC levels indicators.

Keywords: Anemia of pregnant women, KEK, TTD, gold pieces

\section{PENDAHULUAN}

Saat ini masalah gizi di tingkat global dan Indonesia BBLR tetap menjadi masalah, khususnya di negara negara berkembang. Lebih dari 20 juta bayi didunia (15,5\% dari seluruh kelahiran mengalami BBLR dan 95\% diantara nya terjadi di negara berkembang (Kawai K,dkk 2011). Di Indonesia prevalensi BBLR sebesar 6.2\%. Besar kemungkinan kejadian BBLR diawali berasal dari ibu yang hamil dengan kondisi Kurang Energi Kronis (KEK), dan risiko nya lebih tinggi pada ibu hamil usia 15-19 tahun. Dimana proporsi ibu hamil KEK usia 15-19 tahun masih sebesar 33.5\% (Riskesdas 2018).

Peraturan Menteri Kesehatan Nomor 14 tahun 2019 tentang Pelaksanaan Teknis Surveians Gizi menyebutkan bahwa adanya beberapa indikator terkait masalah gizi dan kinerja program. Dua diantaranya indikator masalah gizi tercantum dalam pasal IV ayat (1), yaitu persentase ibu hamil anemia dan persentase ibu hamil berisiko Kurang Energi Kronik (KEK) (Kementrian Kesehatan RI, 2019). Indikator tersebut berkaitan dengan indikator kinerja program kerja gizi pada ayat (2), yaitu cakupan ibu hamil yang mendapatkan Tablet Tambah Darah (TTD) minimal 90 tablet selama masa kehamilan dan cakupan ibu hamil KEK yang mendapatkan makanan tambahan (Kemeterian Kesehatan RI, 2019). Berdasarkan data dari Riset Kesehatan Dasar tahun 2018 menunjukkan capaian kinerja gizi yang masih kurang optimal, persentase ibu hamil yang mendapatkan TTD sebesar 73,2\% (Riskesda, 2018). Persentase tersebut dilihat berdasarkan kuantitas mendapatkan TTD, yaitu ibu hamil anemia yang mendapatkan kurang dari 90 butir (<90 butir) sebesar $61,9 \%$ dan lebih dari sama dengan 90 butir $(\geq 90$ butir) sebesar $38,1 \%$. Data tersebut telah mengalami peningkatan dibandingkan dengan data dari Pemantauan Status Gizi (PSG) tahun 2017, yaitu 52,2\% ibu hamil mendapatkan TTD $<90$ tablet dan 31,3\% ibu hamil mendapatkan TTD lebih dari sama dengan 90 butir ( $\geq 90$ butir).

Anemia merupakan masalah gizi yang mempengaruhi jutaan orang di negaranegara berkembang dan tetap menjadi tantangan besar bagi kesehatan manusia.1 Prevalensi anemia diperkirakan 9 persen di negara-negara maju, sedangkan di negara 
berkembang prevalensinya 43 persen. Anak-anak dan wanita usia subur (WUS) adalah kelompok yang paling berisiko, dengan perkiraan prevalensi anemia pada balita sebesar 47 persen, pada wanita hamil sebesar 42 persen, dan pada wanita yang tidak hamil usia 15-49 tahun sebesar 30 persen.2 World Health Organization (WHO) menargetkan penurunan prevalensi anemia pada WUS sebesar 50 persen pada tahun 2025. Kondisi anemia dapat meningkatkan risiko kematian ibu pada saat melahirkan, melahirkan bayi dengan berat badan lahir rendah, janin dan ibu mudah terkena infeksi, keguguran, dan meningkatkan risiko bayi lahir prematur. Afrika dan Asia, anemia diperkirakan berkontribusi lebih dari 115.000 kematian ibu dan 591000 kematian perinatal secara global per tahun. Konsekuensi morbiditas terkait dengan anemia kronis memperpanjang hilangnya produktivitas dari kapasitas gangguan kerja, gangguan kognitif, dan peningkatan kerentanan terhadap infeksi, yang juga memberikan beban ekonomi. Faktor-faktor yang menyebabkan terjadinya anemia pada populasi melibatkan interaksi kompleks dari faktor-faktor sosial, politik, ekologi, dan biologi. Di antara faktor gizi yang berkontribusi terhadap anemia adalah kekurangan zat besi. Hal ini karena konsumsi makanan yang monoton, namun kaya akan zat yang menghambat penyerapan zat besi (phytates) sehingga zat besi tidak dapat dimanfaatkan oleh tubuh. 10 Kekurangan zat besi juga dapat diperburuk oleh status gizi yang buruk, terutama ketika dikaitkan dengan kekurangan asam folat, vitamin A atau B12, seperti yang sering terjadi di negaranegara berkembang. Penelitian Pala K dan Dundar $\mathrm{N}$ di Turki menunjukkan bahwa faktor lama menstruasi juga berhubungan dengan kejadian anemia. Berkaitan dengan penyakit infeksi, malaria dan kecacingan merupakan penyebab anemia, terutama di daerah endemik.Di samping itu kondisi sosial ekonomi rumahtangga juga terkait dengan kejadian anemia.

Sejalan dengan hal tersebut diatas, maka seyogyanya penanganan masalah gizi tidak bisa dilakukan hanya oleh pemerintah saja, namun perlu keterlibatan dan dukungan dari pemangku kepentingan lain, seperti mitra pembangunan, LSM, perguruan tinggi, organisasi profesi dan organisasi kemasyarakatan sangatlah penting. Oleh karena itu Kabupaten Tanggerang melakukan suatu upaya perbaikan gizi yang berkaitan dengan masalah gizi ibu hamil dengan kondisi anemia dan kekurangan energi kronik (KEK). Salah satu programnya adalah program kader pendamping masa emas atau yang disebut dengan keping emas. Program kader pendamping masa emas (KEPING EMAS) 
mulai dilaksanakan pada September 2019.

Program Keping Emas baru hanya

dilaksanakan di Desa Kronjo yang

merupakan salah satu wilayah kerja

Puskesmas Kecamatan Kronjo, Kabupaten

Tanggerang. Salah satu indikator dari

program tersebut adalah pendampingan

terhadap ibu hamil risiko tinggi yang

mempunyai kondisi anemia dan KEK.

Berdasarkan hal tersebut, penting untuk

mengetahui analisis secara deskriptif

faktor risiko ibu hamil pada pelaksanaan

Program Keping Emas yang telah

dilaksanakan selama tiga bulan. Penelitian

ini bertujuan untuk menganalisis secara

deskriptif faktor risiko ibu hamil pada pelaksanaan program Keping Emas di Desa Kronjo Tahun 2019.

\section{METODE}

Desain penelitian ini menggunakan metode penelitian deskriptif kuantitatif. Dalam Sugiyono (2017) disebutkan bahwa penelitian kuantitatif merupakan metode penelitian yang dalam pengumpulan data menggunakan instrument penelitian dan data yang sudah terkumpul dianalisis dengan menggunakan statistik deskriptif atau inferensial. Data yang terkumpul dari penelitian ini berupa angka dan dianalisis menggunakan statistik (Sugiyono, 2017). Metode penelitian kuantitatif dipilih oleh tim peneliti dilatarbelakangi oleh alasan bahwa, peneliti ingin mendapatkan informasi yang yang luas berkaitan dengan kejadian ibu hamil anemia dan menganaisis peningkatan kadar haemoglobin $(\mathrm{Hb})$ Ibu hamil risiko tinggi anemia dalam program keping emas dan harapannya dengan metode ini peneliti mendapatkan data yang akurat berdasarkan fenomena yang empiris dan dapat diukur.

Populasi dalam penelitian ini terdiri dari populasi target dan terjangkau. Populasi target dalam penelitian ini adalah semua ibu hamil di Desa Kronjo Kecamatan Kronjo. Populasi terjangkau pada penelitian ini adalah ibu hamil berisiko tinggi (anemia dan KEK) yang terlibat dalam program keping emas (September sampai dengan November tahun 2019. Jumlah populasi terjangkau dalam penelitian ini yaitu sebanyak 18 responden.

Sampel penelitian merupakan bagian dari jumlah dan karakteristik yang dimiliki oleh populasi tersebut (Sugiyono, 2017). Sampel yang digunakan dalam penelitian ini adalah ibu hamil berisiko tinggi dengan kondisi anemia dan KEK, yaitu sebanyak 18 responden. Teknik yang digunakan dalam penelitian adalah total sampling, yaitu teknik penentuan sampel apabila semua anggota populasi digunakan sebagai 
sampel. Tahapan yang dilakukan oleh peneliti yaitu sebagai berikut :

1) Mencari informasi jumlah ibu hamil berisiko tinggi dengan kondisi anemia dan KEK sebagai populasi target.

2) Setelah mendapatkan total sampel, peneliti mulai melakukan proses analisis data.

Penelitian ini dilakukan di salah satu wilayah kerja UPTD Puskesmas Kecamatan Kronjo Kabupaten Tangerang, yaitu Desa Kronjo yang juga merupakan wilayah intervensi dari program keping emas tahun 2019. Pelaksanaan penelitian dimulai pada 03 Februari 2019 dengan menggunakan data periode September sampai dengan November 2019. Seluruh data yang sudah diperoleh dari lapangan, peneliti akan melanjutkan proses pengolahan dan analisis data. Dalam proses ini peneliti menggunakan software pengolah data.

\section{HASIL DAN PEMBAHASAN}

\section{Gambaran Karakteristik Umur Ibu Hamil}

Risiko Tinggi dalam Program Keping Emas tahun 2019

Berdasarkan hasil analisis deskriptif terhadap data umur ibu hamil risiko tinggi yang dalam pelaksanaam Progran Keping Emas tahun 2019, didapatkan gambaran karakteristik umur ibu hamil risiko tinggi. Pelaksanaan program dimulai pada bulan September sampai dengan November 2019 yang melibatkan 18 responden. Berikut gambaran karakteristik umur ibu hamil risiko tinggi pada pelaksanaan Program Keping Emas Tahun 2019 (Grafik 1):

\section{Gambaran Karakteristik Umur Ibu Hamil Risiko Tinggi dalam Program Keping Emas tahun 2019}

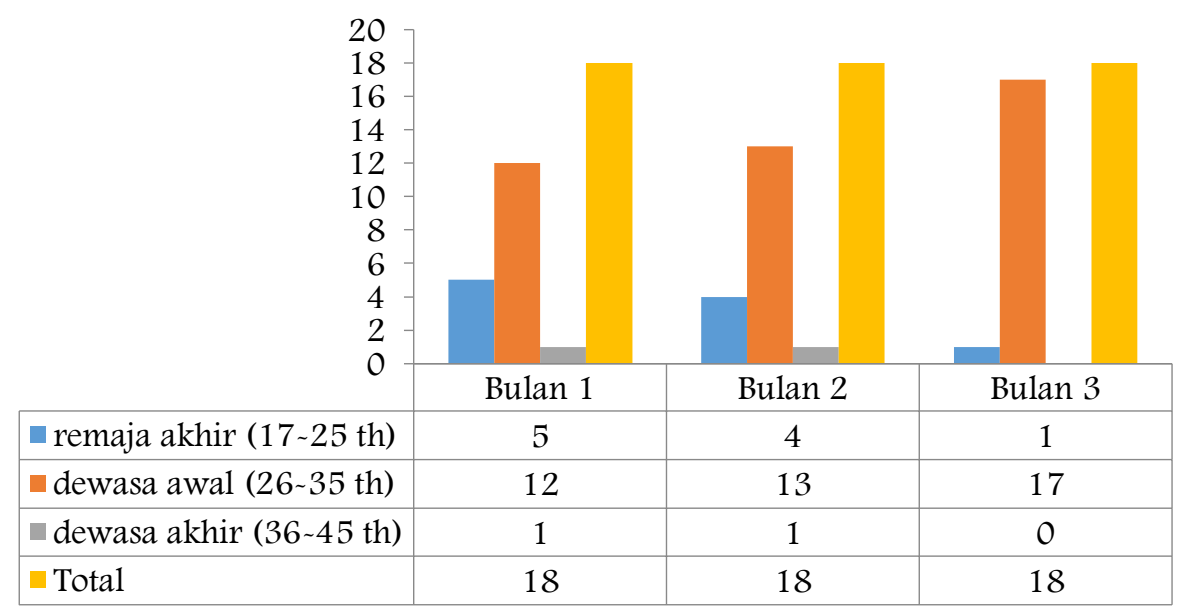

Grafik 1. Gambaran Karakteristik Umur Ibu Hamil Risiko Tinggi dalam Program Keping Emas Tahun 2019 
Berdasarkan Gambar 1, didapatkan informasi bahwa pada bulan pertama pelaksanaan Program Keping Emas (September 2019) kelompok umur ibu hamil risiko tinggi (risti) terbanyak terdapat pada kelompok umur dewasa awal (26-35 tahun) sebanyak 12 orang $(66,7 \%)$. Pada pelaksanaan bulan kedua (Oktober 2019) kelompok umur terbanyak terdapat pada dewasa awal (26-35 tahun) sebanyak 13 orang $(72,2 \%)$, sama halnya dengan bulan pelaksanaan ketiga (November 2019) kelompok umur terbanyak masih pada kelompok umur dewasa awal (26-35 tahun) sebanyak 17 orang (94,4\%). Secara keseluruhan gambaran karakteristik umur ibu hamil berisiko tinggi yang terlibat dalam pelaksanaan Program Keping Emas di Desa Kronjo Tahun 2019 terdapat pada kelompok umur dewasa (26-35 tahun).

Ibu yang berumur dibawah 20 tahun dan lebih dari 35 tahun lebih rentan menderita anemia hal ini disebabkan oleh faktor fisik dan psikis. Wanita yang hamil di usia kurang dari 20 tahun beresiko terhadap anemia karena pada usia ini sering terjadi kekurangan gizi. Hal ini muncul biasanya karena usia remaja menginginkan tubuh yang ideal sehingga mendorong untuk melakukan diet yang ketat tanpa memperhatikan keseimbangan gizi sehingga pada saat memasuki kehamilan dengan status gizi kurang. Sedangkan ibu yang berusia diatas 35 tahun usia ini rentan terhadap penurunan daya tahan tubuh sehingga mengakibatkan ibu hamil mudah terkena infeksi dan terserang penyakit (herawati \& astuti, 2010)

Penelitian yang di lakukan oleh Cucu dkk bahwasanya dari 81 responden, sebagian besar ibu pada umur kehamilan pada trisemster II sama-sama menderita anemia dan tidak anemia dan dari hasil uji hubungan diketahui $p$ value $(0,003)$ yang berarti ada hubungan antara umur dengan kejadian anemia gizi pada ibu hamil. Status anemia pada kehamilan menunjukkan bahwa proporsi anemia pada kehamilan trisemester III sebesar 72.7\% ini menunjukan bahwa umur kehamilan trisemester III lebih banyak menderita anemia dibanding trisemester I dan trisemester II. (herawati \& astuti, 2010).

\section{Gambaran Karakteristik LILA Ibu Hamil}

Risiko Tinggi dalam Program Keping Emas tahun 2019

Gambaran informasi terkait karakteristik responden berdasarkan hasil pengukuran lingkar lengan atas (LILA) ibu hamil risiko tinggi yang terlibat dalam pelaksanaan program keping emas tahun 2019 dapat dilihat pada Grafik 2 : 


\section{Gambaran Karakteristik LILA Ibu Hamil Risiko Tinggi dalam Program Keping Emas tahun 2019}

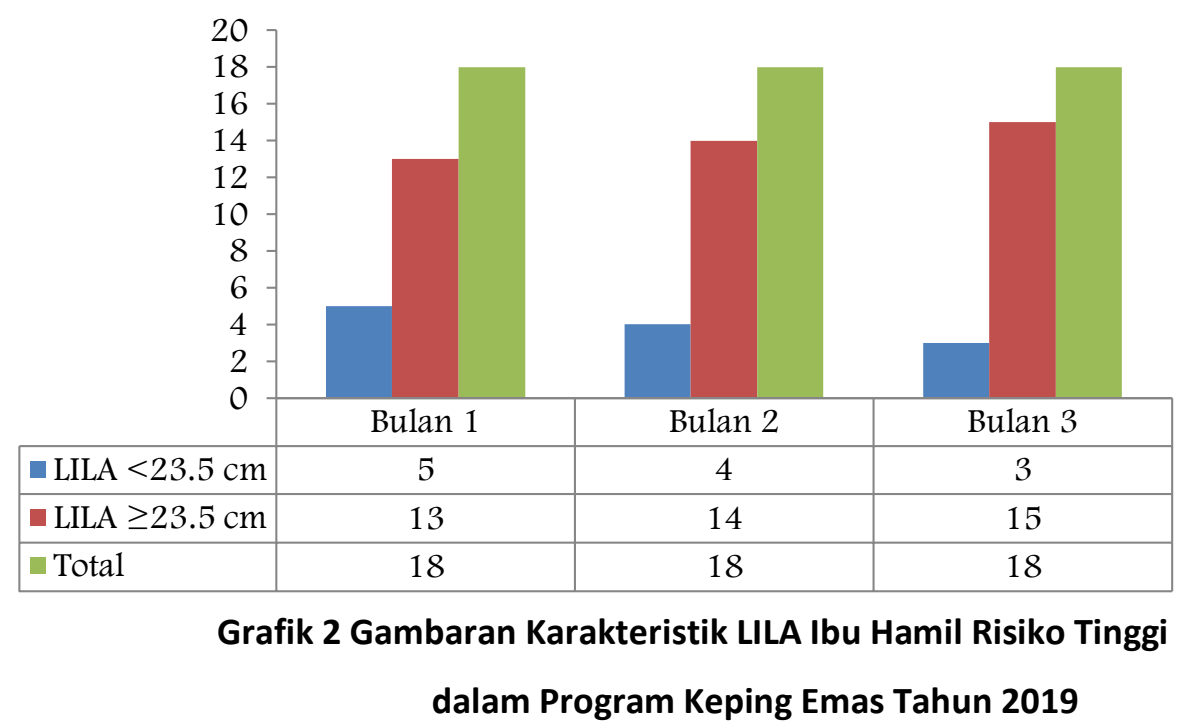

Berdasarkan Grafik 2, didapatkan informasi bahwa pada setiap bulan pelaksanaan Program Keping Emas Tahun 2019 di Desa Kronjo ditemukan atau dilakukan pendampigan terhadap ibu hamil yang berisiko dengan lingkar lengan atas (LILA) kurang dari $23 \mathrm{~cm}$. Pada Bulan pertama (September 2019) didampingi sebanyak 5 orang $(27,8 \%)$ ibu hamil risiko tinggi dengan LILA kurang dari $23 \mathrm{~cm}$, sedangkan pada bulan kedua (Oktober 2019) didampingi sebanyak 4 orang $(22,2 \%)$ serta pada bulan ketiga pelaksanaan program didampingi sebanyak 3 orang $(16,7 \%)$. Ibu hamil berisiko tinggi dengan terbanyak ditemukan pada pelaksanaan program bulan pertama (September 2019).
Kekurangan Energi Kronis (KEK) merupakan suatu keadaan di mana status gizi seseorang buruk yang disebabkan karena kurangnya konsumsi pangan sumber energi yang mengandung zat gizi makronutrien yakni yang diperlukan banyak oleh tubuh dan mikronutrien yang diperlukan sedikit oleh tubuh. Kebutuhan wanita hamil meningkat dari biasanya dan peningkatan jumlah konsumsi makan perlu ditambah terutama konsumsi pangan sumber energi untuk memenuhi kebutuhan ibu dan janin (aminin, wulandari, \& lestari, 2014)

KEK berhubungan dengan kejadian anemia karena erat kaitannya dengan kekurangann asupan protein. Kekurangan energi kronis (KEK) pada ibu hamil 
berhubungan dengann kurangnya asupan protein yang bersifat kronis atau terjadi dalam jangka waktu yang lama. Dengan demikian kurangnya asupan protein akan berdampak pada terganggunya penyerapan zat besi yang berakibat pada terjadinya defisiensi besi. (herawati \& astuti, 2010)

Menurut penelitian Wijianto, dkk, ada hubungan yang bermakna antara resiko KEK dengan kejadian anemia pada ibu hamil .lbu hamil yang berisiko kekurangan energi kronis (KEK) berpeluang menderita anemia 2,76 kali lebih besar dibandingkan dengan yang tidak beresiko. Kontribusi dan terjadinya KEK pada ibu hamil akan mempengaruhi tumbuh kembang janin antara lain dapat meningkatkan resiko terjadinya berat bayi lahir rendah (BBLR). Ibu hamil dengan KEK memiliki resiko kesakitan yang lebih besar terutama pada trimester III kehamilan sehingga dapat mengakibatkan kelahiran BBLR (aminin, wulandari, \& lestari, 2014)

Pemberian zat besi setiap hari merupakan standar dari program pemerintah dan WHO untuk mencegah anemia. Namun pemberian zat besi setiap hari ini memiliki banyak kekurangan terutama terhadap kepatuhan ibu mengkonsumsi zat besi. Penyebab utama rendahnya kepatuhan konsumsi zat besi adalah efek samping setelah konsumsi zat besi berupa mual, konstipasi, feses yang hitam dan rasa besi yang tidak enak. Pencegahan efek samping dari mengkonsumsi zat besi setiap hari sebetulnya dapat dilakukan dengan memahami pola pergantian sel intestinal dalam darah yang dilakukan setiap 5-6 hari. Oleh sebab itu beberapa kajian studi menyebutkan bahwa ibu hamil tidak perlu konsumsi zat besi setiap hari. Tujuan dari pola ini adalah untuk mengurangi kejadian efek samping setelah konsumsi zat besi.

\section{Gambaran Karakteristik Kadar}

Hemoglobin Ibu Hamil Risiko Tinggi dalam Program Keping Emas tahun 2019

Berdasarkan Grafik 3, didapatkan informasi terkait gambaran karakteristik ibu hamil berisiko tinggi dalam Program Keping Emas di Desa Kronjo tahun 2019 berdasarkan kadar hemoglobin $(\mathrm{Hb})$. Berikut gambaran Grafik 3 : 


\section{Gambaran Karakteristik $\mathrm{Hb}$ Ibu Hamil Risiko Tinggi dalam Program Keping Emas tahun 2019}

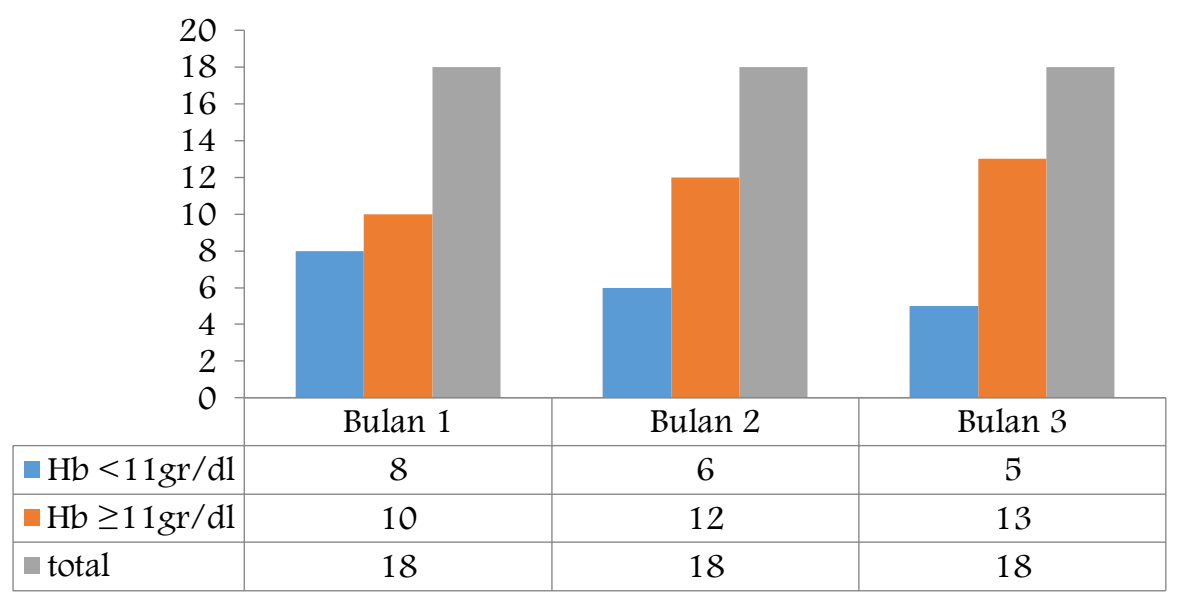

Grafik 3. Gambaran Karakteristik Hb Ibu Hamil Risiko Tinggi dalam Program Keping Emas tahun 2019

Informasi yang didapatkan dari gambaran Grafik 3, bahwa pada bulan pertama (September 2019) pelaksanaan Program Keping Emas tahun 2019 mendampingi sebanyak 8 orang $(44,4 \%)$ dengan kadar hemoglobin kurang dari $11 \mathrm{gr} / \mathrm{dl}$, sedangkan pada bulan kedua (Oktober 2019) mendampingi sebanyak 6 orang $(33,3 \%)$ dengan kadar hemoglobin kurang dari $11 \mathrm{gr} / \mathrm{dl}$. Pada pelaksanaan program di Bulan ketiga (November 2019) mendampingi sebnyak 5 orang $(27,8 \%)$. Ibu hamil berisiko tinggi dengan kadar $\mathrm{Hb}$ kurang dari $11 \mathrm{gr} / \mathrm{dl}$ terbanyak ditemukan pada pelaksanaan program bulan pertama (September 2019).

Gambaran kejadian anemia dan kekurangan energi kronis (KEK) pada ibu hamil yang terlibat dalam program keping emas tahun 2019.

Berdasarkan gambaran Grafik 4, didapatkan informasi terkait ibu hamil berisiko tinggi anemia dengan indikator kadar hemoglobin kurang dari 11gr/dl dan ibu hamil berisiko tinggi KEK dengan indikator lingkar lengan atas kurang dari $23,5 \mathrm{~cm}$. Berikut merupakan gambaran Grafik 4 : 

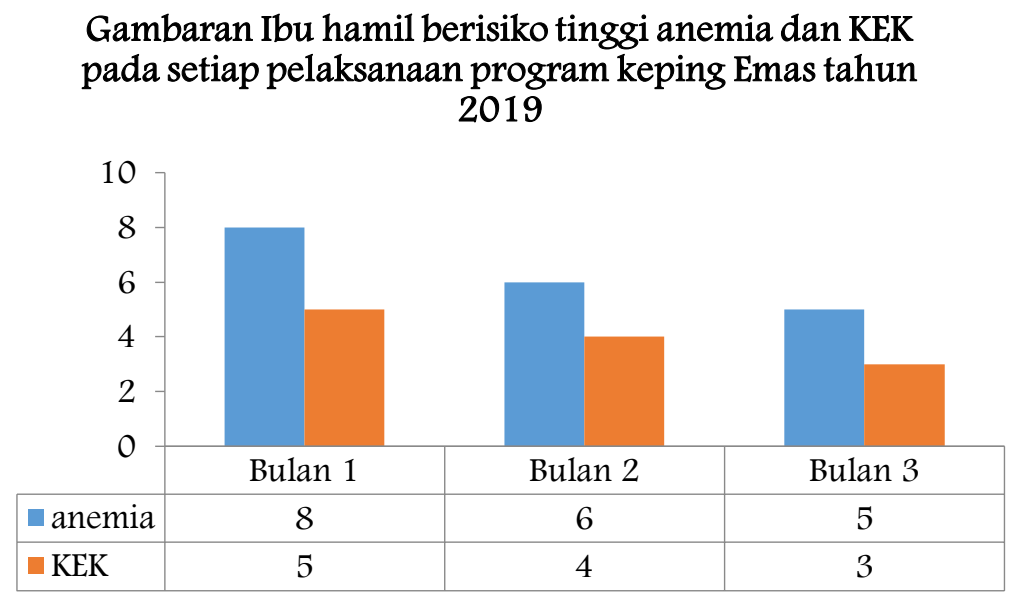

\section{Grafik 4 Gambaran Ibu hamil berisiko tinggi anemia dan KEK pada setiap pelaksanaan} program keping Emas tahun 2019

Berdasarkan Grafik 4, didapatkan informasi bahwa pada bulan pertama pelaksanaan Program Keping Emas di Desa Kronjo tahun 2019 pihak kader mendampingi sebanyak 8 orang $(44,4 \%)$ ibu hamil risiko tinggi anemia dan 5 orang $(27,8 \%)$ ibu hamil berisiko tinggi KEK, pada pelaksanaan bulan kedua mendampingi sebanyak 6 orang (33,3\%) ibu hamil risiko tinggi anemia dan 4 orang $(22,2 \%)$ ibu hamil berisiko KEK, serta pada pelaksanaan program pada bulan ketiga mendampingi sebanyak 5 orang $(27,8 \%)$ ibu hamil berisiko tinggi anemia dan sebanyak 3 orang $(16,7 \%)$ ibu hamil berisiko tinggi KEK. Gambaran status anemia dan KEK pada Ibu hamil berisiko tinggi yang terlibat dalam pelaksanaan program keping emas Tahun 2019 dapat dilihat pada Grafik 5. Pada Grafik 4.5 dapat dilihat bahwa ditemukan ibu hamil risiko tinggi yang mempunyai status anemia berdasarkan indikator kadar hb (<11gr/dl) dan sekaligus mengalami kekurangi energi kronik (KEK) berdasarkan indikator LILA $(<23,5 \mathrm{~cm})$. 


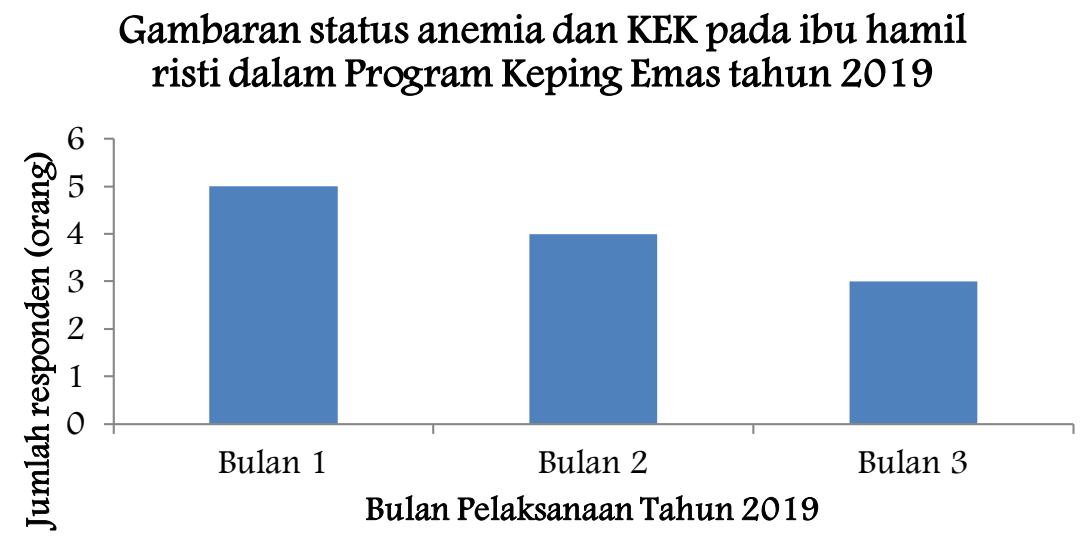

\section{Grafik 5. Gambaran status anemia dan KEK pada ibu hamil risti dalam Program Keping Emas tahun 2019}

Berdasarkan Grafik 5, didapatkan informasi bahwa pada bulan pertama pelaksanaan program Keping Emas di Desa Kronjo Tahun 2019 terdapat 5 orang (27,8\%) yang mempunyai status anemia dan KEK berdasarkan indikator $\mathrm{Hb}$ dan LILA. Pada Bulan kedua pelaksanaan Program Keping Emas terdapat 4 orang (22,2\%) dengan status yang sama serta pada bulan ketiga terdapat sebanyak 3 orang $(16,7 \%)$ dengan mempunyai status anemia dan KEK.

Berdasarkan penelitian yang dilakukan oleh Handayani pada tahun 2013 menyatakan bahwa peran petugas kesehatan atau dalam program ini adalah petugas keping emas harus mampu sebagai komunikator dan fasilitator. Petugas harus memberikan informasi secara jelas kepada pasien. Pemberian informasi sangat diperlukan karena komunikasi diperlukan untuk mengkondisikan faktor kurangnya pengetahuan dan sikap masyarakat terhadap kesehatan dan penyakit. Untuk itu diperlukan komunikasi yang efektf dari petugas kesehatan . Fasilitator juga harus dilengkapi dengan buku pedoman pemberian tablet besi dengan tujuan agar petugas mampu melaksanakan pemberian tablet besi pada kelompok sasaran dalam upaya menurunkan prevalensi anemia karena peran petugas sangat mempengaruhi ibu dalam mengonsumsi tablet Fe.

Hasil penelitian mengenai Studi Farmakoepidemiologi Vitamin Penambah Darah Pada Ibu Hamil Di Kecamatan Jatinangor, yang di publish Jurnal Kesehatan Vokasional 2019, menunjukan bahwa penyebab terbanyak mengapa ibu hamil tidak patuh dalam meminum TTD adalah lupa minum (75\%) dan juga 
sebanyak $45,8 \%$ pernah mengurangi atau berhenti minum suplemen tanpa sepengetahuan petugas kesehatan (dokter/bidan/perawat) dan terdapat 8,3\% merasa terganggu harus minum suplemen vitamin penambah darah setiap hari. Penyebab paling sering responden tidak mengonsumsi tablet zat besi secara teratur atau rutin adalah lupa waktu karena waktu meminum tablet zat besi di malan hari (sebelum tidur). Hasil tersebut sesuai dengan temuan Subarda (2016) di Kabupaten Asahan yang menyatakan bahwa penyebab ibu hamil tidak rutin meminum 18 tablet zat besi adalah lupa. Selain karena lupa responden tidak patuh karena merasakan adanya keluhan setelah meminum tablet zat besi. Keluhan yang dirasakan merupakan efek samping tablet zat besi seperti mual muntah, diare, konstipasi, pusing dan sakit perut. Kondisi tersebut membuat beberapa responden merasa kondisinya semakin memburuk setelah mengonsumsi tablet zat besi. Temuan ini sesuai dengan penelitian Irvina selain karena lupa 30,3\% responden tidak patuh karena merasakan adanya keluhan setelah meminum tablet Fe. Sehingga menyebabkan responden memilih tidak melanjutkan meminum tablet.

\section{SIMPULAN}

Penelitian dilakukan pada 18 orang responden ibu hamil berisiko tinggi (risti) dengan anemia dan KEK, kemudian dilakukan intervensi pemberian Tablet Tambah Darah (TTD) dan Pemberian Makanan Tambahan melalui Program Keping Emas di Desa Kronjo Tahun 2019 selama 3 bulan. Karakteristik umur ibu hamil berisiko tinggi yang terlibat dalam pelaksanaan Program Keping Emas di Desa Kronjo Tahun 2019 terdapat pada kelompok umur dewasa (26-35 tahun). Ibu hamil dengan LILA $<23,5 \mathrm{~cm}$ paling banyak didampingi pada Bulan pertama (September 2019), yaitu sebanyak 5 orang $(27,8 \%)$ dan ibu hamil dengan $\mathrm{Hb}<11 \mathrm{gr} / \mathrm{dl}$ terbanyak didampingi pada bulan pertama (September 2019) pelaksanaan Program Keping Emas tahun 2019 mendampingi sebanyak 8 orang $(44,4 \%)$.

Perencanaan Program dan Koordinasi antar stake holder perlu dijalankan dengan baik, termasuk KEPING EMAS sebagai program unggulan Kab Tanggerang, sehingga program prioritas ini menjadi program unggulan yang berkelanjutan.

\section{DAFTAR PUSTAKA}

Aditianti, dkk. 2015. Pendampingan Minum Tablet Tambah Darah (TTD) dapat Meningkatkan Kepatuhan Konsumsi TTD pada Ibu Hamil Anemia (Family and Cadre Support Increased Iron Pils Compliance In Anemic Pregnant 
Women). Jurnal Penelitian Gizi da

$\begin{array}{lll}\text { Makanan. } \quad 38 \quad \text { (1). } & \text { 71-78. }\end{array}$

https://media.neliti.com/media/p

ublications/223565-

pendampingan-minum-tablet-

tambah-darah-t.pdf (diakses pada :

24 Februari 2020).

Aherawati, c., \& astuti, s. (2010). FAKTOR-

FAKTOR YANG BERHUBUNGAN

DENGAN ANEMIA GIZI PADA IBU

HAMIL. Jurnal Kesehatan Kartika.

Aminin, f., wulandari, a., \& lestari, r. p.

(2014). PENGARUH KEKURANGAN

ENERGI KRONIS (KEK). Jurnal

Kesehatan.

Novyriana, E., Rahmadhani, w., \& zuhroh,

S. (2016). HUBUNGAN LINGKAR LENGAN ATAS DENGAN KEJADIAN ANEMIA. Jurnal IImiah Kesehatan Keperawatan.

Anggraeni, S dkk. 2014. Kadar

haemoglobin pada lbu Hamil Tidak

Berhubungan dengan Pola

Konsumsi Zat Besi. Jurnal IImiah

Kesehatan. (3). Lampung

https://www.researchgate.net/pu

blication/334650828 Kadar Hemo

globin Pada Ibu Hamil Tidak Ber

hubungan Dengan Pola Konsums

i Zat Besi (diakses pada 24

Februari 2020)

Herawati, c., \& astuti, s. (2010). FAKTOR-

FAKTOR YANG BERHUBUNGAN

DENGAN ANEMIA GIZI PADA IBU

HAMIL. Jurnal Kesehatan Kartika
Kementerian Kesehatan Republik

Indonesia. 2014. Peraturan

Menteri Kesehatan Republik

Indonesia Nomor 88 Tahun 2014

tentang Standar Tablet Tambah

Darah Bagi Wanita Usia Subur dan

Ibu Hamil. Jakarta : Kemenkes RI

Kementerian Kesehatan Republik

Indonesia. 2016. Peraturan

Menteri Kesehatan Republik

Indonesia Nomor 51 Tahun 2016

tentang Standar Produk

Suplemtasi Gizi. Jakarta :

Kemenkes RI

Kementrian Koordinator Bidang

Kesejahteraan Rakyat. 2012.

Gerkan Nasional Percepatan Gizi

Dalam Rangka 1000 hari Pertama

Kehidupan. Jakarta. MenkoKesra RI

Kementerian Kesehatan Republik

Indonesia. 2019. Peraturan

Menteri Kesehatan Republik

Indonesia Nomor 14 Tahun 2019

tentang Pelaksanaan Teknis

Surveilan Gizi. Jakarta : Kemenkes

RI.

Novyriana, E., Rahmadhani, w., \& zuhroh,

S. (2016). HUBUNGAN LINGKAR

LENGAN ATAS DENGAN KEJADIAN

ANEMIA. Jurnal Ilmiah Kesehatan

Keperawatan.

Nuraeni, dkk. 2019. Peningkatan Kadar Haemoglobin melalui Pemeriksaan dan Pemberian Tablet Fe terhadap 
Remaja yang Mengalami Anemia

melalui Gerakan Jumat Pintar.

Jurnal Pengabdian kepada

Masyarakat. 5 (2). 200-221.

https://jurnal.ugm.ac.id/jpkm/arti

cle/view/40570 (diakses pada : 24

Februari 2020).

Sugiyono. (2017). Metode Penelitian Kombinasi (Mixed Method) (8th ed.). Bandung: Alfabeta.

Wahyuni, S. 2018. Efektivitas Pendampingan Minum Tablet Tambah Darah (TTD) oleh Kader Posyandu terhadap Peningkatan Kadar Hb lbu Hamil di Puskesmas Kota Palangkaraya. Jurnal Surya $\begin{array}{llll}\text { Medika. } & 3 & \text { (2). } \quad 82-94 .\end{array}$

https://media.neliti.com/media/p ublications/258706-efektifitas-

pendampingan-minum-tablet-ta-

084291ca.pdf (diakses pada : 24

Februari 2020).

WHO. 2012. Daily Iron and Folic Acid Supplementation in Pregnant Women. Geneva : World Health Organization.

https://apps.who.int/iris/bitstrea $\underline{\mathrm{m} / \text { handle/10665/77770/97892415 }}$ 01996 eng.pdf;jsessionid=CEA393 03FA1BC2058AFB57232DA87B9?s $\underline{\text { equence }=1}$ (diakses pada : 24 Februari 2020) 